ForInternational Handbook of Wealth and the Super-Rich

\title{
Interrogating the legitimacy of extreme wealth: a moral economic perspective
}

Andrew Sayer, Lancaster University, September, 2014

\begin{abstract}
The main task of a moral economic approach to extreme wealth is to interrogate the justifications of the sources of income of the wealthy. By developing and applying distinctions between earned and unearned income, and between investment that produces development (wealth creation) and 'investment' that merely allows wealth extraction, it will be shown that the usual justifications of extreme wealth hold little water. It then looks at evidence regarding the sources of income of the wealthy and how these have changed. The remarkable return of the rich in many countries over the last 30+ years involves a shift not only from labour to capital, but from productive capital to rentiership in the financial and property sectors - and hence wealth extraction.
\end{abstract}

\section{Introductioni}

Thanks in particular to the work of Thomas Piketty and Emmanuel Saez, it has become clear that the rich and super-rich have made an extraordinary comeback since the 1970s. This phenomenon is most clear in English speaking countries in which neoliberalism, and with it, financialization, have been strongest. As their data shows, the proportion of national income received by the top $1 \%$ and fractions thereof in these countries over the last 100 years follows a U-shaped curve, bottoming out in the post-war boom; in the UK it fell from over $18 \%$ in the 1920 s to $6 \%$ in the 1970 s, from which it recovered to over $15 \%$ by 2007 , followed by a temporary dip and then recovery. Sweden and Norway have shallower U-shaped curves. Italy, Spain, New Zealand, and Argentina have also seen a return of the rich, albeit with more fluctuations. China, of course, has seen a dramatic rise in top incomes in recent years. The return of the rich is much more limited in France, Denmark and Japan, which have more L-shaped curves. In Germany, the share of national income taken by the $1 \%$ has stayed fairly flat but at a relatively high level since the war. In the Netherlands and Switzerland the income shares of the top $1 \%$ have fallen since the post-war boom. .i Whereas $^{\text {i }}$ the Great Depression of the inter-war period was accompanied and followed by a fall in the proportion of income going to the rich, the recent major recession has seen continued accumulation by the $1 \%$ and massive and rapid concentration of wealth at the top in many countries. In 2014 in the UK, the wealth of the richest 1000 people totalled $£ 519$ billion, having grown by over $15 \%$ since 2012 . (1997 figure was $£ 98$ billion). The latest figure is enough to fund the entire National Health Service for 4.2 years. ${ }^{i i i}$ Danny Dorling has shown that, over a century (1910-2009), the shares of total income of those within the different fractions of the top $1 \%$ in the UK changed together, and rose and fell in the opposite 
direction to the shares of the bottom 99\%: when the 1\% got more, the $99 \%$ got less (Dorling, 2013). But in the UK, as elsewhere, it is primarily those at the top of the $1 \%$ who have benefitted most.

Both to explain and to evaluate such changes, we need to identify the sources of income received by the rich. Particularly, for the latter we need to adopt a moral economic approach to understanding economic activities. By this I mean one that examines and assesses the moral justifications of basic features of economic organization, in particular property relations and what institutions and individuals are allowed and required to do. It treats the economy not merely as a machine which sometimes breaks down, but as a complex set of relationships between people, increasingly stretched around the world, in which they act as producers of goods and services, investors, recipients of various kinds of income, lenders and borrowers, and as taxpayers and consumers. As a critical approach it goes beyond the usual focus on irrationality and systemic breakdown, to injustice and the moral justifications of taken-for-granted rights and practices. It's not only about how much people in different positions in the economy should get paid for what they do, but whether those positions are legitimate in the first place. Is it right that they're allowed to do what they're doing? One can use the term moral economy also to refer to a kind of economy, as Edward Thompson famously did, but unlike him, though like many more recent users of the term, I regard all economies as moral economies in some respects (Sayer, 2007).iv

A moral economic approach defines economies as systems of provisioning, including but going beyond the cash economy. Economic activity provides usevalues, whether material (e.g. food) or immaterial (e.g. school lessons, carework), some of which may be commodified, that is, produced for sale. It takes seriously the indisputable fact that we all are social beings, dependent on others as well as ourselves for our survival and well-being. No-one is or ever was 'independently rich': financial wealth is just a claim upon wealth in terms of usevalues produced by others. Unless there are things for sale, money is worthless, and things for sale have to be produced, though not all products need to be produced for sale. Production is prior to exchange.

The concerns of moral economy as an approach include the large differences between what some are able to get and what they contribute, need and deserve. What people should get - a focus of a large literature in political philosophy, including John Rawls' famous $A$ Theory of Justice - is a difficult issue, particularly where it's a matter of what we think people deserve or merit. But what people actually get and do in a capitalist economy have little to do with moral judgement. Particularly in the case of the rich, it can be shown that what they get has more to do with power. I argue that the rich get most of their income by using control of assets like land and money to siphon off wealth that others produce. Much of their income is unearned. What's more, over the last 35 years, particularly with the increasing dominance of the economy by finance ('financialization'), the rich have become far richer than before by expanding these sources of unearned income. But while the distinction between earned and unearned income was a staple of classical political economy, socialist thought, and taxation policy, it has fallen out of use in the last 35 years - precisely the 
period in which unearned income has grown. We need, then, to clarify this distinction. But first it's necessary to disambiguate another key term in our economic vocabulary: 'investment'.

I shall start with these matters of definition and then proceed to provide evidence for my central claim, that the extraordinary growth of the wealth of the rich and super-rich stems from the expansion of unearned income.

\section{Investment}

There is a fundamental and deceptive slippage in the use of the word 'investment'. This slippage is central to the legitimation of the rich, and their symbolic domination. Investment is invariably understood to be a good thing, and can provide an appealing cover for a vast range of activities, yet the term is used in two radically different senses:

(1) Use-value/object-oriented definitions focus on what it is that is invested in, for example, infrastructure, equipment, or training, that enhance what people can do. I.e. it focuses on wealth creation.

(2) Exchange-value/'investor'-oriented definitions focus on the financial gains from any kind of lending, saving, purchase of financial assets or speculation - regardless of whether they contribute to any objective investment (1), or benefit others. Here the focus is wealth extraction. Henceforth I shall use scare quotes for this second meaning of the term.

This is not just an academic distinction: the difference between the two activities is of enormous practical importance for both economic growth and wealth distribution.

The standard move is to elide the distinction and pass off the second as based on the first. Sometimes the two may indeed go together. But it is also perfectly possible for successful investments in the first sense to fail to provide financial benefits to 'investors' in the second sense. The use of my taxes for investing in infrastructure on the other side of the country may benefit others but not me. Conversely, it is equally possible for lucrative 'investments' in the second sense to have neutral or negative effects on productive capacity - through, asset stripping, value-skimming, and rent-seeking. Elisions of this vital distinction have become commonplace not so much through a desire to deceive than through ignorance, coupled with the fact that under capitalism individuals have little or no interest in checking whether their 'investments' (2) have positive, neutral or negative effects on the production of goods and services; to the rentier-'investor', $£ 1$ million from rent is no different from $£ 1$ million from new productive capacity. Further for particular 'investors', though not for whole economies, purely extractive kinds of 'investment' such as speculating on asset bubbles can be less risky than objective, wealth-creating investment.

Given the huge difference between these two meanings of the same word, and the contingent relation between the practices to which they refer, we must be on 
our guard when rich or super-rich individuals justify their wealth by claiming to be 'investors'.

\section{The earned-unearned income distinction and its application}

This distinction is fundamental both for understanding economic functions and how distribution is determined, and for evaluating such distributions in ethical terms. Roughly speaking, earned income is what employees and self-employed people get from contributing to the production of goods and services. I don't mean to suggest that the size of their pay reflects what they deserve or contribute, but rather that their pay is at least conditional on providing goods and services that others can use. The relation between what we might think people deserve for their work - however we might want to measure that - and the income they actually get is pretty loose, not least because pay levels are influenced by power and scarcity rather than such considerations. The goods or services they produce and deliver have 'use-value', that is, qualities that make them useful or desirable, such as the nutritious and tasty quality of a meal, or the educational qualities of a maths lesson. Many of these products and services are sold in exchange for money in markets, and so have not only use-value but 'exchange-value' and hence are commodities. But many are funded by taxes, providing income for state sector workers, such as police officers and school teachers. Public sector workers, no less than private sector workers, can produce wealth - useful goods and services. These goods and services have costs of production - wages and salaries, the care, education, training and support that enables people to work, and the costs of producing the materials used in the process. Some work has a more indirect relation to the production and distribution of goods and services, but is nevertheless necessary for efficient provisioning. For example, accounting is needed to monitor and manage the use of money and other resources in organisations; an insurance industry is important for providing security; and a legal system and police force are needed to protect people and property.

By contrast, unearned income derives not from providing goods or services that would not otherwise exist and hence incur costs of production, but from controlling an already-existing asset, such as land or buildings or spare money, that others lack but need or want, and who can therefore be charged for its use. If the asset already exists, and there are no further costs of production apart from for maintenance, then those who receive income from it do so not because they are in any sense 'deserving' - they have not contributed anything that did not previously exist - but because they can. It is a reflection of power deriving from unequal control over existing assets. They use their property not as means of production or 'means of work but as an instrument for the acquisition of gain' (Tawney, 1921, pp.65-6). This is what Ruskin called 'illth', deriving from what J. A. Hobson later called 'improperty' (Ruskin, 1862; Hobson, 1937). In most cases they have this power of control by virtue of property rights that legally entitle them to use it for extracting payments from others who lack access to such assets. Whereas earned income is work-based, unearned income is asset-based. In political economy, a person who derives unearned income from ownership of existing assets is known as a rentier. 
Insofar as owners can extract money from others and hence be able to buy goods and services without producing goods and services in exchange, then those who are producing goods and services must be producing more than they themselves consume. In other words, they must be producing a surplus. Mere ownership alone produces nothing. The rentier is essentially siphoning off wealth produced by others. In turn, this implies that those who rely on earned income are generally paid less than the value of what they produce.

The owners of such assets aren't the only ones who are able to consume without contributing to production of use-values, however. Children, the elderly and sick and those unable to work also get a kind of unearned income, whether provided by families or the state. However, these flows of money are generally called 'transfers' rather than 'unearned income' because they are believed - quite reasonably - to be accepted as warranted on the basis of needs: producers are unlikely to object to having to produce a bit more than they themselves consume in order to support them. In practice, just who is deemed entitled to this income varies between societies, but it's generally based on a mixture of recognition of others' needs, love in the case of family members, sense of civic duty, and prudent self-interest (in providing a safety net, should things go wrong). The prime justification is usually that the recipients are needy and cannot reasonably be expected to work for an income, or that there are insufficient jobs for them, and that unemployment and ill-health can happen to anyone. As always, which transfers are undertaken by the state's taxation and spending depends of course on the politics and balance of power in the country concerned.

But while the transfers that they get are relatively easy to justify, the unearned income of adult, able-bodied rentiers is unwarranted and undeserved. They freeride on the labour of others. The term "free-riding" both denotes a particular kind of economic social relation and raises ethical objections to it. This relation between rentiers and producers is indisputably a social relation, one that is exploitative and an important generator of inequality in its own right. It is a relation that has become increasingly complex and globalized, so that British rentiers, for example, siphon off wealth produced by workers not only in Britain but in many other countries. Let us now examine the main sources of unwarranted, or asset-based unearned income, starting with the classical trio of rent, interest and profit.

The clearest case of the rentier is the landowner. The mere ownership of land or buildings does not make it any more productive, and while it can be claimed that improvements to them should be paid for because they involve production costs and produce enhanced goods, pure rent is not payment for production but merely for access; as Tawney observed, rent is like a private tax on the industry of others (Tawney, 1921). Sources of rent other than land and property, such as intellectual property also provide rentier income - income based on power rather than contribution.

Interest on loans is a charge for the use an existing asset - money - which functions as a claim on the labour and products of others. However, banks do not 
merely act as intermediaries between savers and borrowers by lending their existing deposits, but create new credit money, simply by writing deposits into the accounts of borrowers; the interest they charge far exceeds any production costs in creating the credit money (Hudson, 2011; Mellor, 2010). Deregulation has allowed them a freer hand in doing this. Lending that fuelled asset price bubbles was a major component of the 2007 credit crunch, and has had important effect on shifting patterns of economic inequalities, enriching the asset-rich at the expense of the asset-poor (Engelen et al, 2011). For Marx, it was primarily those who made money out of money -'interest-bearing capital' - who made up 'the class of parasites' (Marx, 1972, p. 545). A moral economic critique of interest situates it in an unequal social relation - usury - in which the lender is typically in a stronger position than the borrower. Although interest payments are taken for granted in contemporary capitalism, outside the formal economy, they are seen as unjust. If we are in financial difficulties and ask a friend for a loan, we would be outraged if they said yes but only on condition that we paid interest and agreed to release our assets as collateral should we not be able to repay. It would be perfectly clear to us that they were taking advantage of our weakness. The injustice of this asymmetry has been the focus of critiques of usury for millennia (Graeber, 2011; Pettifor 2006).

In classical political economy, profit is the third member of this trio of sources of unearned income. The profits of private (productive) employers derive from their ownership of the means of production and the product, and the dependency of non-owners of means of production on them for employment. Pure capitalists - that is ones who just own their firms and delegate management to others - are not contributing to wealth creation, but merely using their power relative to those of propertyless workers to appropriate the difference between costs and the value of what the workers (and managers) produce. Their income is unearned. In these respects, pure capitalists profiting merely from owning businesses producing goods and services look very much like rentiers. But there's also a difference. Even though their income is unearned, it has a 'saving grace': it is at least dependent on supporting productive activity. While, like rentiers, pure capitalists also depend on this surplus for their profit, they are also instrumental in making the generation of that surplus possible, and can only make a profit as long as they do. What is remarkable, though unremarked because it has become normalised with the establishment of capitalist property rights, is that the employees who produce the goods and services have no rights over the revenue that comes from the sale of their output, and no say in what happens to it.

For working capitalists, those who are not only owners but managers, their income is a mixture of both earned and unearned. In practice, the distinction between employee managers and capitalists and rentiers can be blurred by giving them shares. As organized labour has weakened and delivering shareholder value has become a priority, top managers have been able to use their power to increase their pay in return for maximizing gains for shareholders. 
Shares provide another major source of unearned income. Since well over 97 per cent of share transactions are in the secondary market, only in a tiny proportion of cases does the money paid for them go to the company, and thus might be claimed to be a payment for contributing to any objective productive investment. The extraordinary feature of share ownership is not so much limited liability (for losses made by the company) but that it provides a potentially indefinite source of unearned income - an unlimited asset. Both dividends and gains from trading shares are important sources of unearned income. Since growth of demand for shares has exceeded the growth of supply in recent decades, average prices have tended to rise too, creating bubbles, so this source has proved lucrative (Engelen et al, 2011). The development over the last 30 years of the shareholder value movement - a highly successful rentier campaign - coupled with the weakening of trade unions, has made share prices the primary concern of the management of companies. Firms that fail to deliver rising share prices - for example, by ploughing most of their profits into productive investment instead of distributing them as dividends - are disciplined by the market for companies as they become vulnerable to takeover by managements that will deliver shareholder value. Particularly in the light of the power of uncommitted, absentee shareholders, what is remarkable - though unremarked because it has become normalised with the establishment of capitalist property rights - is that the employees who produce the goods and services have no control over the revenue that comes from the sale of their output. A relevant moral economic question is what is the justification for this extraordinary difference between the position of workers dependent and committed - and that of owners who are usually uncommitted and have contributed little or nothing to the work of the organisation?

The financial boom and crisis owed much to unearned income from speculation on an ever-growing range of financial assets, and from burgeoning tax avoidance, even as taxes on capital fell. Many in the sector have made their money by arranging major transactions such as mergers and takeovers, involving many millions of pounds, and taking a small percentage commission. It is in their interest to promote as many transactions as possible. In effect, they are standing 'close to a big till',v and it is easy for them to put their hands in it without breaking any laws; the income reflects position rather than contribution. Erturk et al call this 'value-skimming' and argue that the financial intermediaries have been a major but hidden beneficiary of financialization, overlooked by those who limit their gaze to bankers or CEOs. High-income but largely anonymous financial intermediaries far outnumber the much-publicised CEOs; Savage and Williams estimate that in the City of London there are circa 15,000 senior intermediaries employed at a principal or partner level in investment banking, hedge funds and other kinds of trading and private equity (as well as those providing support services in law and accounting) (Savage and Williams, 2008).

Contemporary mainstream economists are of course likely to object to this account. One of the things financial systems, whether privately or publicly run, are supposed to do is move underused or idle resources, particularly savings, to where they can be used more productively, thereby promoting 'allocational efficiency'. The money made by those who do this is supposedly a reward for enabling this. However, this definition is frequently used as a cover for a quite 
different version of allocational efficiency that is specific to capitalism, in which the allocation of resources among competing ends is according to where expected rates of financial return are highest. This could be where labour is most exploitable, where consumer incomes are highest, where prospects for extracting rent are best, or where asset inflation is highest (for example, the latest bubble), or where taxation is lowest. It could be logging in Sumatra, or mining in Peru, or luxury apartments in London, or buying up land in Africa to rent out, or buying shares, bonds or other financial instruments.

\section{Sources of the wealth of the rich}

So far I have sketched out the main sources of unearned income involving wealth extraction, but I have yet to show that they are the main source of the wealth of the rich. The relative enrichment over the last 35 years of the top $1 \%$ or $0.1 \%$ of individuals in the income distribution gives us something to explain but says nothing about the sources of their income. While there is no single source of evidence that covers this comprehensively, a consistent picture emerges from a variety of sources.

It might be thought that one could just define wages and salaries as earned income and subtract them from total income, to get unearned income - receipts of rent, interest, profit, capital gains and speculative gains. But in contemporary economies many of the richest get most of their income in salaries. This makes it appear that rentier-dominated economies are a thing of the past, because now 'the working rich' make up most of the rich and super-rich. But this approach seriously underestimates unearned income as we have defined it, and hence the extent of rentiership. The reason for this is that some people get a salary for performing wealth extraction activities for rentier organizations. ${ }^{v i}$ So although their income comes in the form of salary and is recorded as such, it is actually rent or interest or profit from mere ownership, etc., at one remove. Property companies and banks, particularly 'investment' banks and much of the rest of the financial sector are prime examples of organizations most of whose activities fit this description. And as many commentators have noted, it is particularly in these (FIRE) sectors that the astonishing growth in incomes, including salaries, at the top has occurred. Further, in the last 30 years, many non-finance companies, from cars to public utilities, have made more money by getting involved in rentier activities in the financial sector than in their traditional sectors, so these increasingly supplement the incomes of the 'working rich' in these sectors too.

Over the years 1979-2012, the top 1\% of US households increased their real incomes by $185 \%$, the top $0.1 \%$ by $384 \%$, and the top $0.01 \%$ by $685 \%$, while those of the vast majority of the rest stagnated (Sayer, 2014, p.x). vii To say the least, it would stretch credulity to claim that this growth of top incomes reflected equivalent increases in their economic contributions. While the share of national income going to workers over the last 35 years has fallen in many countries, labour productivity continued to rise, so 'jobless growth' predominated. According to Tom Palley 'wages of U.S. production and non-supervisory workers (who constitute over 80 percent of employment) have become detached from 
productivity growth during the era of financialisation' (Palley, 2007). In the UK the divergence between pay and productivity started later, in the 1990s, and was less dramatic but still marked. Again, only the pay of those at or near the top of the income distribution kept up with economic growth. The weakening of trade unions and employment protection has hit those in the bottom half of the income distribution hardest; the decline in trade union membership correlates with the rising income shares of the top 1\% (Oxfam, 2014). In so far as there has been an expansion of employment, it is because a larger proportion of jobs are part time, and low paid, and there has been a rapid growth of self-employment - more likely to be a sign of precarity than security (Buchanan et al, 2013).

Several studies have revealed similar if not quite so dramatic patterns in a large number of countries:

- In a study of 13 western capitalist countries, John Peters found that while workers achieved a $4 \%$ growth in real wages in the 1970s, growth in real wages from 1980 to 2005 was less than 1\%, though those employed in the financial sector did better. In the 1970s and 1980s the wage share of national income in these countries peaked at $78 \%$, but then declined to $63 \%$ in 2005 while income from profits, stock dividends, interest and rents rose (Peters, 2010; see also Perrons, 2012).

- Tali Kristal's 2009 study of labour's share of national income in 16 capitalist democracies arrived at 'an unequivocal conclusion. Since the early 1980s there has been a large and persistent decline in labor's share of national income in most capitalist democracies. The growth of productivity has expanded total income, but in many countries average real wages and fringe benefits have increased more slowly than labor productivity. Meanwhile, income growth has occurred mainly in capitalists' profits, sharply increasing capital's share.'viii

- The United Nations Conference on Trade and Development (UNCTAD) commented: 'In developed countries, the share of labour income declined, falling by 5 percentage points or more between 1980 and 2006-2007 just before the global financial crisis - in Australia, Belgium, Finland, France, the Netherland, Norway, Sweden, the United Kingdom and the United States, and by 10 points or more in Austria, Germany, Ireland, New Zealand and Portugal. In several major economies (including France, Germany, Italy and the United States), a significant proportion of the decline in the share of wages had already occurred between 1980 and 1995. This appears to have been linked to a departure from the post-war social consensus, when wage increases closely followed productivity gains (UNCTAD, 2012, p.52).

- The International Labour Organization (ILO) found that between the early 1990s and 2007, labour's share of income fell in 51 out of the 73 countries for which data was available. More specifically, labour's share of value added fell by 13\% in Latin America, 10\% in Asia and the Pacific and 9\% in high-income countries. The gap between the top and bottom $10 \%$ of waged and salaried workers increased in $70 \%$ of countries in this survey (ILO, 2008). ${ }^{\text {ix }}$ 
- Both UNCTAD and the ILO show that in most developed countries, especially English-speaking ones, income from capital gains (unearned income) has gone increasingly to the rich. ${ }^{x}$

- Reports from the International Monetary Fund (IMF), the Organization for Economic Cooperation and Development (OECD) and Oxfam also show a widening of inequalities in most countries, with the rich pulling away from the rest (IMF, 2008, p.168). ${ }^{x i}$

But is this increasing proportion of income going to those at the top a reflection of an increase in their contribution to wealth creation, rather than simply increased wealth extraction? Some argue that recent technological change has favoured higher-paid workers who have the necessary skills, but, as the exhaustive analyses of Thomas Piketty show, if this were the case one would expect wage shares across the top 10 or $20 \%$ to have increased, when in fact increases have been heavily concentrated in the top 1\% (Piketty, 2014). And when we look at the sectors in which the rich are concentrated - finance and real estate - it is clear that the 'earnings' of many of 'the working rich' come from interest, rent-seeking and value-skimming, albeit paid out as salaries and share options. Particularly between 2000 and 2008, an increasing share of growth was taken as profit by owners and shareholders, contributing further to the divergence of wages and productivity growth (Resolution Foundation, 2012).

Interest payments yield unearned income for lenders, and since lenders tend to be richer than borrowers, interest filters up to the top. In Britain, Hodgson has estimated that only the top $10 \%$ get more in interest then they pay out, and within them it's the $1 \%$ who get most (Hodgson, 2013). ${ }^{x i i}$ In Germany, the bottom $80 \%$ of people in the income distribution pay out far more interest on loans and hidden in the prices of goods than they get back on savings - not surprisingly, for as elsewhere few of them can afford to save much. Those in the next $10 \%$ get roughly as much interest as they pay out, while those in the top $10 \%$ get more than they pay out, and within that group the richest of course enjoy the biggest surplus (Kennedy, 2012).

All this is consistent with the argument, made by David Harvey, that there has been a shift from the primary circuit of capital (centred on the production of goods and services) to the secondary circuit of capital in which capital is 'invested' in assets such as land, property, loans, shares, and a vast range of financial instruments (Harvey, 2007). This shift, which began in the 1970s, occurred partly because profit margins were being squeezed in the primary sector, due to a combination of increased competition from cheap labour countries and strong labour organization in many sectors in the old industrialised countries. Meanwhile, the growth of private pensions 'invested' in financial products by pension funds and other major harvesters of the savings of the middle classes increased demand for them. But whereas growing demand for everyday products like pizzas and mobile phones prompts increased supply, the same is not true for many key financial assets. Corporations are generally reluctant to issue new shares, because this risks lowering their share prices, and indeed many have spent more on buying back their own shares than on real investment, so increased demand for them has driven up their prices - and with 
that, top managers' bonuses. Land and property in central locations is also inherently scarce, unless one builds upwards, and property companies have no interest in stopping the inflation of land and property values by building enough to meet demand. Privatization of public utilities also creates lucrative sources of rent from the control of water and energy; as James Meek puts it, our need for these things has been turned into 'a human revenue stream' (Meek, 2012). These can in turn be securitized and the income paid out as dividends used as ways for the companies to load up with debt and avoid tax (Allen and Pryke, 2013). The 'working rich' in these companies are the chief beneficiaries of this shift towards rentiership.

'Wealth', in the financial sense, covers many things but is typically defined as total stock of a person's assets minus liabilities. While for most of the $99 \%$ their wealth, from homes to clothes, is a stock of use-values, for the $1 \%$ and particularly those at the top, most of their wealth is primarily an 'investment', used to gain income from ownership of capital assets, via interest, dividends, profits, and capital gains. And as Thomas Piketty shows, in many countries, wealth from these sources has been increasing faster than from others sources primarily wages and salaries - in the neoliberal era. In fact, looking back over a century, the half century from 1920s to the 1970s was an anomaly in capitalist history because it was the only time when the ratio of wealth from these sources relative to total income fell significantly. It happened as a result of the growing strength of labour and the destruction of capital, particularly in the Second World War. Since then the rate of growth of unearned income (not a term Piketty makes much use of) has exceeded the rate of economic growth, resulting in rapid wealth concentration at the top, at the expense of the majority of the population. Provided the rich 'invest' most of their money rather than spend it on consumption, this process will continue, and, as one would expect, the richer they are the higher their marginal propensity to 'invest'. This concentration of wealth means that the children of the wealthy, already advantaged through no effort of their own, will inherit huge windfalls - the purest case of unearned income. (Bequests might seem like transfers, as they're gifts, but they differ in that they are not based on need; in fact, given that the children of the rich receive far more than others, they are inversely related to need.) As Piketty notes this means we are returning to an 'inheritance society' in which there is not only a very high concentration of wealth but large fortunes are passed from generation to generation and social mobility is restricted (Piketty, p.351). In France, he estimates that inherited wealth already accounts for a fifth of household monetary resources, and is rising fast. xiii

\section{Other moral economic critiques of extreme wealth}

Although I have concentrated on the sources of the wealth of the rich, a moral economic critique of their wealth could go beyond this, to include the effects on the distribution of political power, their consumption patterns, and environmental considerations. Here I will sketch what these topics might include: 
As regards the political aspects, the massive concentration of wealth over the last 35 years has been both cause and consequence of a shift in political power to the rich. In any capitalist economy, those who control the commanding heights of the economy have a structural source of power deriving precisely from this control, which makes governments dependent on them for delivering economic growth. In the neoliberal era this hidden power has been augmented through the weakening of the power of organised labour, as already mentioned. But in addition to the shift in power from labour to capital there has been a shift within capital towards that which dominates the secondary circuit, particularly finance, and with that rentier capitalism. By constructing a narrative of success and modernity, by lobbying, by dominating the media, by buying support through political donations, and infiltrating government and designing policies that suit its interests, this new financial plutocracy has huge influence on political agendas. Its most brilliant coup has been to offload the costs of its financial crisis onto the $99 \%$, and the blame onto the public sector. Its next coup is likely to be pushing through bold new trade treaties that allow big capital to override legislation approved by democratic governments that limits its power. These are the Trans-Pacific Pact (TTP), involving 12 nations round the Pacific Rim, ${ }^{\text {xiv }}$ and the Transatlantic Trade and Investment Partnership (TTIP) involving the US and 28 European Union states. Together they account for $60 \%$ of global output. Any state that tries to impose restrictions on capital, say, to protect the environment or protect labour and human rights, regulate finance or and keep its public sector public or restrict the growth of corporate property rights is liable to be sued by an closed international court. Few elected politicians have been allowed access to the negotiations or even information about their details. 'Investor-state dispute settlement' mechanisms are to be used to allow big corporations to sue governments before secretive arbitration panels composed of corporate lawyers, bypassing domestic courts and overriding the will of parliaments. This represents a huge victory for plutocracy over democracy. The increased political power of capital committed to increasing its already bloated unearned income is truly a force to be reckoned with.

As regards consumption, it has again to be remembered that financial wealth constitutes a potential claim on the goods and services produced as commodities by others. Unless the latter are produced, the wealth is worthless. Thus, a relevant moral economic question might be what justification is there for the work of so many to be controlled by the consumption preferences of so few? One way of thinking about how much concentration of wealth should be allowed is to ask how many people's labour and pay should be dependent on meeting the consumption desires of the rich and super-rich? Carlos Slim Helu (net 'worth' $\$ 87$ billion, in 2014), for many years the richest man in the world, owns $90 \%$ of the telephone landlines in Mexico, and $80 \%$ of the mobile phone networks, an extraordinary politically mediated windfall of economic rent (Thompson, 2006). ${ }^{\mathrm{xv}}$ His income in 2012 was equivalent to the average annual salary of 400,000 Mexicans (Freeland, 2012). If he were to spend it all on consumption one can imagine how large the disproportion would be between production for and production for his benefit. Such inequalities in what people are able to consume creates a massive misallocation of resources, in which the production of exclusive luxuries takes precedence over production for the needs and wants 
of the vast majority of population, particularly the poor. Increased consumption by the rich can actually make others worse off: in London, purchase of properties as 'investments' by the rich not only allows them both to drive up and free-ride on rising land values, but makes it increasingly difficult for many who work in the capital to live there.

Finally, as regards the environment, a moral economic approach would question the legitimacy of allowing any to consume more than their share of the earth's resources, ie. the world's resources divided by the world's population? To be sure, some may need to consume more than others, for example, people in cold countries need more fuel for heating and insulation than those in hot countries. But in practice, of course, the distribution is not determined by deliberation but by power; why should we assume that the distribution resulting from a free-forall in which those who control key assets can extract wealth from others must be acceptable? This kind of question is particularly urgent as carbon emissions continue to accumulate, rapidly approaching the point where runaway global warming takes off. Why should anyone be allowed to produce more green house gases from their activities than the earth's capacity to reabsorb it (already massively exceeded) divided by the world's population? But it is not just that the carbon footprints of rich individuals are so excessive, but that insofar as their wealth depends on continued exponential economic growth, so they can get a return on their 'investments', they have an interest in doing nothing about climate change. Energy companies - amongst the most powerful corporations in the world - are continuing their long-term investment in fossil fuels, and the repayment of debts to the rich depends on economic growth.

\section{Conclusion}

Much could be added to this explanation of the growth of rentiership, of unearned income based on control of assets, in particular changes in global economic geography. There is also a cultural side to it, as neoliberalism has infiltrated ever deeper into organizational and everyday life, changing behaviours and worldviews. Part of this in turn has been the piecemeal development of narratives celebrating 'the market' and its 'Masters of the Universe' and encouraging the financialization of everyday lifexvi - through exhortations to 'release the value' of our homes', become 'entrepreneurial selves', 'leveraging our skillsets'. It also 'moralized' neoliberalism with a discourse of 'wealth creation', 'trickle down effects', the rich as job creators specially gifted individuals who we should admire and thank. Ordinary people have been encouraged to see themselves as responsible only for themselves, rather than interdependent, while marketing and managerial discourse strives to create optimism - a 'cruel optimism'xvii - in the face of job insecurity, massive youth unemployment and prohibitive housing costs.

Many academics and other observers have become fascinated with the challenge of understanding the extraordinary complex and arcane practices of financialization - often with a sense of dismay at the way the sector has come to function as master rather than servant of the economy. Many have pointed out how dysfunctional it is to have economies in which the falling share of wealth 
held by the $99 \%$ results in stagnation of demand and hence reduced capacity for paying debt. But the economy is not just a devilishly complex and flawed machine: while it certainly is dysfunctional and contradictory, it is also a set of social relations and there is a danger of missing the injustice of this wealth concentration, insofar as comes from unearned income, from a massive increase in free-riding. Similarly, debts piled up into the future can only be repaid if the output produced by future generations grows fast enough. Given the size of the debt crisis, this is clearly an impossibility. More importantly, in a world on the brink of runaway global warming, resumed growth in countries with already massively unsustainable carbon footprints is madness - again not only dysfunctional, but unjust in damaging the environment of poorer countries and future generations. Hence the need for a moral economic approach that questions all this and reveals the role of the rich in it.

\section{References}

Allen, John and Mike Pryke (2013), 'Financializing household water: Thames Water, MEIF, and ring-fenced politics', Cambridge Journal of Regions, Economy and Society, 6 (3): 419-439

Alperovitz, Gar and Lew Daly (2010) Unjust deserts, The New Press.

Berlant, Lauren (2011) Cruel Optimism, NC: Duke University Press.

Booth, William (2004) 'On the idea of the moral economy', American Political Science Review, 88, 3, 653-667.

Buchanan, J., Dymski, G., Froud, J., Johal, S., Leaver, A. and Williams, K. (2013) 'Unsustainable employment portfolios.' Work, Employment and Society, 27, 396413.

Dorling, Danny (2013), 'Fairness and the changing fortunes of people in Britain', Journal of the Royal Statistical Society A, 176, 1, 97-128.

Engelen, Eward et al (2011) After the Great Complacence: Financial Crisis and the Politics of Reform. Oxford: Oxford University Press.

Erturk, Ismail, Froud, J., Leaver, A., and Williams, K. (2007) 'Agency: a positional critique' Economy and Society, 36 (1): 51-77.

Freeland, Chrystia (2012) Plutocrats: The rise of the new global super-rich, London: Allen Lane, p 195.

Graeber, David 2011 Debt: the first 5000 years, Melville House Publishing. Harvey, David (2007) A brief history of neoliberalism, Oxford: Oxford University Press

Hobson, J.A. (1937) Property and Improperty. London: Gollancz.

Hodgson, G. (2013) 'Banking, finance and income inequality', Positive Money https://www.positivemoney.org/publications/banking-finance-and-incomeinequality/

Hudson, Michael (2011) 'How economic theory came to ignore the role of debt' Real World Economics Review, 57, 6 ${ }^{\text {th }}$ September 2011, www.paecon.net;

IMF (2007) Spillovers and cycles in the global economy.

ILO (2008) World of work report.

Keat, Russell (2010) 'Every economy is a moral economy', available at unpublished manuscript, University of Edinburgh, http://www.russellkeat.net Kennedy, M. (2012) Occupy money, New Society Publishers 
Kristal, Tali (2010), 'Good times bad times: postwar labor's share of income in 16 capitalist democracies', American Sociological Review, 75(5), 729-63.

Martin, Randy (2002), The Financialization of Everyday Life, Temple University Press.

Meek, James (2012), 'Human Revenue', London Review of Books, 34: 8. Mellor, Mary (2010), The Future of Money: From Financial Crisis to Public Resource. London: Pluto Press.

Murphy, Liam and Nagel, Thomas (2005), The myth of ownership, Oxford: Oxford University Press.

John O'Neill's (1997), The market, London: Routledge.

Marx, K. (1972), Capital, Volume III, London: Lawrence and Wishart, p.545.

OECD (2011), Divided we stand: Why inequality keeps rising, Paris: OECD.

Oxfam 2014 'Working for the few: political capture and economic inequality', 178 Oxfam Briefing Paper.

Palley, Thomas (2007), 'Financialization: what it is and why it matters' Working Paper 525, Levy Economics Institute, Washington D.C.

Perrons, Diane (2012), “'Global' financial crisis, earnings inequalities and gender: towards a more sustainable model of development', Comparative Sociology, 11, pp 202-26.

Peters, John (2010), 'The rise of finance and the decline of organised labour in the advanced capitalist countries', New Political Economy, 16(1), pp 73-99, at p 93.

Pettifor, Ann (2006), The Coming First World Debt Crisis, Houndmills, Basingstoke, Palgrave

Piketty, Thomas (2014), Capital in the $21^{\text {st }}$ century, Cambridge, MA: Belknap, Harvard.

Polanyi, Karl (1947), The Great Transformation, NY: Basic Books. Resolution Foundation (2012), Gaining From Growth: The Final Report of the Commission on Living Standards,

http://www.resolutionfoundation.org/media/media/downloads/Gaining from growth - The final report of the Commission on Living Standards.pdf.

Ruskin, John (1862) Unto This Last, reprinted in 2007, FQ Classics

Savage, Mike and Karel Williams (2008), 'Elites: remembered in

Capitalism and forgotten in social science', The Sociological Review, 56 (s1): 1-24

Sayer, Andrew (2007), 'Moral economy as critique', New Political Economy, 12 (2), 261-270.

Sayer, Andrew (2014), Why We Can't Afford the Rich, Bristol: Policy Press. Shutt, Harry (2009), The Trouble With Capitalism, London: Zed Books. Tawney, R.H. (1921), The Acquisitive Society. London: G. Bell and Sons, pp.65-6

Thompson, G. (2006), 'Prodded by the left: richest man talks equity', New York Times, 3 June,

http://www.nytimes.com/2006/06/03/world/americas/03slim.html?pagewant ed=1\&_r=0\&ei=5088\&en=87ff5ffac4ee12aa\&ex=1306987200\&partner=rssnyt\& emc $=r s s$.

UNCTAD (2012), Trade and development report. 
i This article is based on arguments developed more fully in my 2014 book.

ii World Top Incomes Database. See Piketty, (2014) for details and analysis. However, these are figures for pre-tax income, and since taxes on the rich have fallen dramatically in the last 30 years, their post-tax income share has risen more.

iii Source: Sunday Times Rich List and UK public spending

http://www.ukpublicspending.co.uk/central spending 2013UKbs

iv Many associate the term 'moral economy' with Edward Thompson's research on regulated markets (1971) 'The moral economy of the English crowd in the Eighteenth Century', Past \& Present, No. 50, pp. 76-136. Thompson used the term to refer to an object rather than as a kind of analysis. As such he saw 'the' moral economy as the opposite of the market economy. See: http://humanitiesunderground.wordpress.com/2012/04/22/the-moral-economics-ofwellbeing/Unfortunately this historical focus has led many to assume that moral economies ended with capitalism, and that capitalism is not in any sense a moral economy. I and other more recent commentators argue it is., e.g.: Booth, 2004; Keat, 2010; The works of O'Neill, 1997; Alperovitz and Daly, 2010; Murphy and Nagel 2005; Graeber, D. 2011; Polanyi, K. 1947 The Great transformation, NY: Basic Books are all consistent with this view.

v Erturk, I., Froud, J., Leaver, A., and Williams, K. (2007) 'Agency: a positional critique' Economy and Society, 36 (1): 51-77.

vi Surprisingly Thomas Piketty misses this point, interpreting the rising wealth of

'supermanagers' in part to the expanding 'earned income hierarchy'. (Piketty, p.378).

vii Citing data from Census Bureau and Economic Policy Institute compiled by Colin Gordon. Incomes include transfers. Average top incomes (market income only) from Piketty and Saez, World top incomes database.

viii According to Harry Shutt, at the same time returns on 'investments' have been 'higher than in any period of comparable length since the Industrial Revolution', with an estimated $75 \%$ of this resulting from appreciation of assets in the US and Britain, compared with well under $50 \%$ on average from 1900 to 1979 (Shutt, 2009, p.124).

ix ILO (2008) World of work report.

$x$ The same trends of falling labour shares are reported in IMF (2007) Spillovers and cycles in the global economy, p 168, though workers in sectors employing a large proportion of graduates increased their shares.

xi See also: OECD (2011) Divided we stand: Why inequality keeps rising, Paris: OECD. I am grateful to Diane Perrons for alerting me to these reports.

xii While this is interesting, it represents national financial systems as closed rather than part of an international system; it also ignores mechanisms of redistribution from poor to rich that do not depend on the creation of interest bearing credit money.

xiii Ibid. p. 404 Partly because of the limitations of Piketty's neoclassical framework, he misses many of the moral economic implications of the trends that he tracks. See for example, his equivocal and evasive assessment of rent and rentiers, in which he seems to imply that mere ownership of productive assets like machinery actually produces something, so that profit is just a payment for that 'contribution' (pp. 422-444). While he calls for redistribution of wealth via a wealth tax (no small thing!) and does refer to rent and rentiers he accepts many of the basic economic institutions that allow unearned income to be extracted and accumulated in the first place.

xiv Canada, US, Mexico, Peru, Chile, New Zealand, Australia, Brunei, Singapore, Malaysia, Vietnam and Japan.

xv Thompson, G. (2006) 'Prodded by the left: richest man talks equity', New York Times, 3 June, http://www.nytimes.com/2006/06/03/world/americas/03slim.html?pagewanted=1\&_r=0\&ei= $5088 \&$ en $=87 \mathrm{ff5ffac} 4 \mathrm{ee} 12 \mathrm{aa} \& \mathrm{ex}=1306987200 \&$ partner=rssnyt\&emc $=$ rss.

xvi Martin, R. 2002, The Financialization of everyday life, Temple University Press

xvii The phrase is Lauren Berlant's, though she uses it somewhat differently from how I have used it here. Berlant, L. (2011) Cruel Optimism, NC: Duke University Press. 